\title{
Abdominal pain and haematochezia in a 45-year-old woman with rheumatoid arthritis receiving adalimumab treatment
}

\author{
Anasua Deb ๑ ${ }^{1}$ Thanita Thongtan $\odot,{ }^{1}$ Michael Phy, ${ }^{1}$ Vanessa Costilla ${ }^{2}$
}

'Department of Internal Medicine, Texas Tech University Health Sciences Center, Lubbock, Texas, USA ${ }^{2}$ Gastroenterology, University Medical Center, Lubbock, Texas, USA

\section{Correspondence to} Dr Thanita Thongtan; thanita.thongtan@ttuhsc.edu

Accepted 3 June 2021
Check for updates

(C) BMJ Publishing Group Limited 2021. No commercial re-use. See rights and permissions. Published by BMJ.

To cite: Deb A, Thongtan T, Phy $\mathrm{M}$, et al. BMJ Case Rep 2021;14:e244130. doi:10.1136/bcr-2021244130

\section{DESCRIPTION}

A 45-year-old woman presented to the emergency department (ED) with severe pain in the left lower abdomen, which was characterised as sharp, cramping, non-radiating and precipitated by food intake. She had experienced constipation for 3 days, which she treated with over-the-counter laxatives. She passed grossly bloody bowel movements while she was in the ED. Her medical history included seronegative rheumatoid arthritis (RA) diagnosed 1 year ago, hypertension, coeliac disease and internal haemorrhoids for which she underwent banding. She took weekly methotrexate and fortnightly adalimumab infusions for RA well as Losartan/Hydrochlorothiazide for hypertension. She was on a gluten-free diet for coeliac disease.

Physical examination revealed tachycardia, diffuse tenderness over lower abdomen and haematochezia. There were no signs of joint inflammation or any deformity. Laboratory evaluation was remarkable for mild leucocytosis with white cell count of $9.57 \times 10^{9} / \mathrm{L}$, high sensitive $\mathrm{C}$ reactive protein of $32.5 \mathrm{mg} / \mathrm{L}$ and lactate level of $3.9 \mathrm{mmol} / \mathrm{L}$. The coagulation profile was normal. The abdominal CT scan was unremarkable. She underwent oesophagogastroduodenoscopy, which showed evidence of acute gastritis and flattened mucosa in the duodenum indicative of her coeliac disease.

Colonoscopy showed diffuse severe inflammation characterised by edematous mucosa, scattered erosions, erythema and longitudinal ulcerations (colon single stripe sign) distributed from the rectosigmoid colon to the hepatic flexure (figure 1). Histopathology examination of the colon depicted crypt loss, lamina propria hyalinisation and congestion, confirming ischaemic colitis (figure 2).

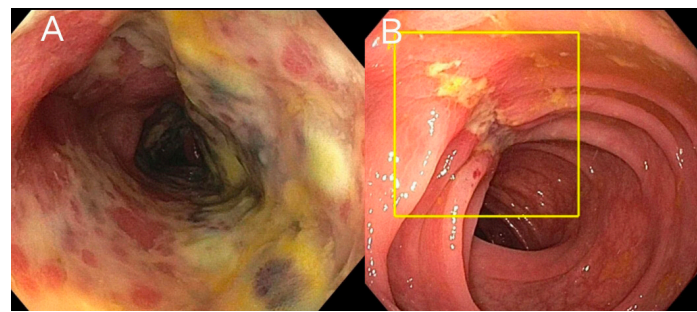

Figure 1 (A) Colonoscopy showed diffuse severe inflammation characterised by edematous mucosa, scattered erosions and erythema in the transverse colon. (B) Colonoscopy showed longitudinal ulcerations (colon single stripe sign) in the descending colon.

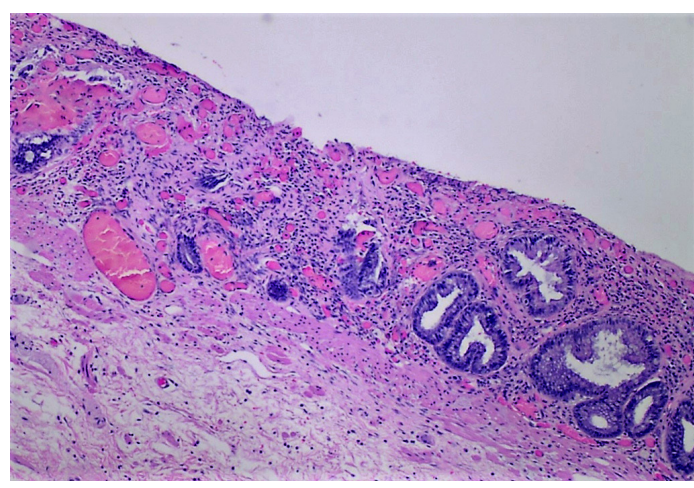

Figure 2 H\&E staining of the descending colon biopsy depicted crypt loss, lamina propria hyalinisation and congestion, confirming ischaemic colitis.

Ischaemic colitis is a rare complication of rheumatoid vasculitis. ${ }^{12}$ Tumor necrosis factor (TNF)- $\alpha$ inhibitors, commonly used biological agents in RA, are also reported to cause ischaemic colitis, through an unknown mechanism. ${ }^{3}$ Such widespread localisation of the lesions, rather than watershed zones, goes against hypoperfusion as a cause of ischaemic colitis. Our patient was diagnosed with seronegative RA and was treated with adalimumab. Since she lacked other symptoms of RA flare and had only mildly elevated non-specific inflammatory markers, ischaemic colitis from rheumatoid vasculitis complication was unlikely. Adalimumab was suspected to cause ischaemic colitis in our patient. Methotrexate and adalimumab treatments were withheld and her haematochezia, leucocytosis and lactic acidosis resolved spontaneously after 3 days of symptomatic management. Abdominal pain improved with opioids and dicyclomine. Haemoglobin remained stable

\section{Learning points}

Abdominal pain and haematochezia in patients with rheumatoid arthritis should raise concern for rheumatoid vasculitis of colonic blood vessels. However, if patients are on TNF- $\alpha$ inhibitor, an alternate diagnosis is anti-TNFinduced ischaemic colitis.

- Discontinuation of the offending agent and treatment with alternative medications can lead to resolution of anti-TNF-induced ischaemic colitis 
during the hospital course and she continued to remain free of symptoms of abdominal pain and haematochezia during further follow-up.

Acknowledgements We thank Dr. Irfan Warraich for histology images and his assistance with the case.

Contributors AD was involved in patient care and drafting of the manuscript. TT was involved in drafting of the manuscript. MP and VC were involved in patient care and revision of the manuscript. All authors have approved the final draft submitted.

Funding The authors have not declared a specific grant for this research from any funding agency in the public, commercial or not-for-profit sectors.

Competing interests None declared.

Patient consent for publication Obtained.

Provenance and peer review Not commissioned; externally peer reviewed.

\section{ORCID iDs}

Anasua Deb http://orcid.org/0000-0002-1049-5882

Thanita Thongtan http://orcid.org/0000-0002-0729-2451

\section{REFERENCES}

1 Rife C, Brunson B, Comerford L. Rheumatoid vasculitis as a cause of colonic ulceration and hemorrhage 902. Am Coll Gastroenterol 2010;105 https://journals.Iww.com/ajg/ Fulltext/2010/10001/Rheumatoid_Vasculitis_as_a_Cause_of_Colonic.902.aspx

2 Nguyen AL, Yap JE, Kotwal V. A Pain in the Colon: Rheumatoid Arthritis as an Unusual Cause of Colonic Ischemia: 1556. Off J Am Coll Gastroenterol. 113 |ACG [Internet]., 2018. Available: https://journals.Iww.com/ajg/Fulltext/2018/10001/A_Pain_in_the_ Colon_Rheumatoid_Arthritis_as_an.1556.aspx

3 Salk A, Stobaugh DJ, Deepak P, et al. Ischaemic colitis in rheumatoid arthritis patients receiving tumour necrosis factor- $\alpha$ inhibitors: an analysis of reports to the US FDA adverse event reporting system. Drug Saf 2013;36:329-34.

Copyright 2021 BMJ Publishing Group. All rights reserved. For permission to reuse any of this content visit

https://www.bmj.com/company/products-services/rights-and-licensing/permissions/

BMJ Case Report Fellows may re-use this article for personal use and teaching without any further permission.

Become a Fellow of BMJ Case Reports today and you can:

- Submit as many cases as you like

- Enjoy fast sympathetic peer review and rapid publication of accepted articles

- Access all the published articles

Re-use any of the published material for personal use and teaching without further permission

\section{Customer Service}

If you have any further queries about your subscription, please contact our customer services team on +44 (0) 2071111105 or via email at support@bmj.com.

Visit casereports.bmj.com for more articles like this and to become a Fellow 